remains unanswered, with regard to the rectification of the circle."

Last year, Lindemann, starting from Hermite's researches, succeeded in supplying the proof required with reference to the number $\pi$. And while speaking of this achievement with the satisfaction which his generous nature prompted, Henry Smith added that it was a problem on which he had long fixed his eye with a view to attacking it seriously so soon as he had leisure for the undertaking.

He was doubtless then looking forward to some University vacation; for vacation time formed the period for his original investigations, while term time was devoted to current work and to society, which he himself so keenly enjoyed, and in which he was always an honoured and a welcome guest.

It has been much the fashion of late years to raise memorials to the departed; and in some cases it may be doubted whether a wise discrimination has been exercised in the matter. No one, however, who has any interest in science, would doubt for a moment that the memory of Henry Smith was in the highest degree deserving of perpetuation. But in our opinion the best and only suitable memorial of him will be the publication of his works, in the fullest and most complete form of which they are now capable. And it is sincerely to be hoped that his MSS. may be placed in the hands of a mathematician who may prefix to them an introduction as worthy of these works as was Prof. Smith's introduction to the remains of Clifford.

During his last few years he lived, as Keeper of the University Museum, at the house adjoining the main building, previously occupied by his predecessor, John Phillips. His companion was his sister, whose useful and sympathetic life worthily supplemented his own. It is to be hoped when the wave of sorrow which is now passing over her has in some degree subsided, and when time has brought an alleviation which may now seem impossible, that she may derive satisfaction, although it be a melancholy one, in having learnt through the event how much her brother was appreciated and beloved by many, and by some even unknown, friends.

\section{W. SPOTTISWOODE}

\section{PUBLIC ELECTRIC LIGHTING}

$\mathrm{M}$ $\mathrm{UCH}$ attention is being given at the present moment to the operation of the Electric Lighting Act: passed during the last session of Parliament. Under the terms of that Act, licenses and provisional orders will be granted to local authorities, companies, and private individuals to supply electricity for the purpose of electric lighting over definite areas. A large number of applications for licenses and provisional orders have already been submitted to the Board of Trade, in a few instances by local authorities, but in the majority of cases by joint-stock companies formed for working one or other of the different systems for electric lighting. A number of the "Provisional Orders" now being promoted lie before us, the majority of them being drawn in almost identical terms. A perusal of these documents cannot fail to impress the reader, firstly, with the great complexity of the question, secondly, with the extreme difficulty of striking a fair balance between vested interests and public convenience, thirdly, with the great amount of knowledge and skill displayed in the drafting of these provisional orders. It is an open secret that not only the main outlines but also most of the details of these orders are from the hand of Mr. J. Fletcher Moulton, F.R.S., whom we must congratulate upon the success with which he has applied himself to the task of preparing them. Now that Parliament is once more in session we shall probably hear of further legislative proposals; but if all provisional orders are as well and as wisely drawn as the majority of those before us appear to be, there can be little doubt that the necessity for separate further legislation and for the promotion of private bills for electric lighting will be removed.

As to the provisional orders themselves it would be impossible within reasonable limits to deal with a tithe of the important topics which are therein set forth. Many of the provisions are naturally directed toward questions of municipal rights and parochial law. Leaving aside all these matters we come to the more scientific points. Four separate systems of distribution are recognised in the provisional orders. These are $(a)$ "direct" system, more familiar under the name of distribution in parallel arc, with "distributing mains" throwing off "service lines" for individual consumers; (b) "storage" system, with service lines in parallel arc from storage batteries charged in series intermittently from a generating station; (c) either of the above with "earth " returns ; $(d)$ "series" system, supplying customers in one undivided circuit. We may remark in passing that it appears to us that the use of "earth" for return should be in every case forbidden. If currents of the intensity employed for electric lighting are sent through earth in our crowded cities we shall have constant derangements of telegraphs, telephones, electric bells, in fact of all electric appliances which work by feeble currents and use earth returns. Moreover, as "earth" in practice means usually the employment of existing gas-pipes or water-pipes as returns the proposal to utilise "earth" for electric light returns, is doubly to be deprecated. Amongst other limitations set forth in the provisional orders are some which bind the "undertakers" to lay down their mains within two years, some which prescribe the hours during which the supply of currents must be maintained, and some which limit the conditions of supply. Amongst the latter we observe in several of the orders before us that it is proposed that "the potential at corresponding points of the positive and negative distributing mains shall differ at each point by a constant difference, not being less than thirty volts, and not being more than four hundred volts." And that "such constant difference of potential" is to be termed "the standard pressure." It is to be hoped that the Board of Trade will be much more precise in its limitations. Thirty volts is so low a "pressure" as to be practically out of the question except with a gigantic outlay in copper conductors, whilst four hundred volts is equally inadmissible on account of the danger to person. No less an authority than Sir W. Thomson has said that nothing above two hundred volts should ever be admitted into a dwelling-house. The provision that "the standard pressure may be different for different points of the said mains, and for different hours during the period of supply" 
is bad, and if permitted will greatly militate against convenience and uniformity in using the current both for light and for motive-power. Where the undertakers distribute "alternating" currents it is provided that the mains should have a "constant (?) difference of potential" or standard pressure of not less than forty-five and not more than six hundred volts. Here again we think that the Board of Trade might very wisely insist on a further restriction. If steady currents at a pressure of four hundred volts are dangerous, alternating currents at four hundred are far more so. Yet here the undertakers talk of six hundred! Indeed, considering the risks involved, and the difficulty in distributing alternating currents through long lines or lines where there is great self-induction; and also considering that the supply of electric currents is not for lighting alone but for the providing also of motive-power, it would not be any loss to the public if the use of alternating currents under the provisional orders were absolutely disallowed. It is true that the patentees of certain specific forms of machine might cry out loudly against such a prohibition; but the public would be guaranteed against one source of danger and difficulty. According to the orders the undertakers may charge consumers either by the amount of electric energy consumed, or by the quantity of electricity supplied, or by time, or by a yearly agreement. In connection with the first of these methods the proposal is made to call by the name "one unit" the energy contained in a current of rooo amperes flowing under an electromotive force of one volt during one hour. Most of the provisional orders name sevenpence per unit as the price of electrical energy. We have here for the first time an actual quotation-price for energy; a fact which should be interesting to those who have striven so hard to drive into the popular mind exact ideas concerning energy and its conservation. One "unit" thus defined for commercial purposes being 1000 volt-amperes (i.e. 1000 watts) for one hour, and one horse-power being 746 watts, we see that the scale of payment is about $5 \frac{1}{3}$ pence per hour per (electrical) horse-power.

Into the further provisions for the inspection and testing of mains, the inspection of meters, the testing of insulation, provisions for safety, and penalties for default in supply, we cannot here enter. Suffice it to say that there is no detail that does not appear to have had thought expended upon it, no provision that is really superfluous or harassing, no possible want or eventuality that does not appear to have been anticipated. Such masterly treatment cannot but greatly facilitate the work of the Board of Trade in agreeing to orders and licenses, and will tend to bring about unity of method in the organisation of the actual work of laying down town supplies so soon as such orders and licenses shall have been granted. If it be true that the effect of the Electric Lighting Act has been to produce a temporary lull in the progress of electric lighting, we are convinced that such a lull will be in the end an unmixed good, since it gives the opportunity for thought to ripen, and for projects and inventions to mature, if not to survive. Two dangers indeed seem yet possible in the future of public electric lighting, and either of them may be sufficiently serious to damage public confidence in this new industrial factor. Firstly, some better guarantees ought to be insisted on that the
Companies or other parties who obtain orders or licenses as undertakers should be possessed of capital adequate to carry out the projects in hand. A very hasty glance at the list of applicants for provisional orders will suffice to show that this fear is not unfounded. Secondly, it ought to be made impossible for a Company which has obtained an order for any limited district to delegate the responsibility of supplying any section of such district to a subcompany. No Company should be allowed to hold a monopoly (if the limited monopoly created by the provisions of the Electric Lighting Act be a monopoly at all) of a single square yard of territory which it cannot with its own resources supply under the terms of the order or license which has been granted. If this principle be not upheld, serious abuses will creep in, to the detriment of progress and in contravention of the interests of the public.

\section{CRYPTOGAMIC FLORA OF GERMANY.} AUSTRIA, AND SWITZERLAND

Dr.L. Rabenhorst's Kryptogamen-Flora von Deutschland, Oesterreich, und der Schweiz. Zweiter Band: Die Meeresalgen Deutschlands und Oesterreichs. Bearbeitet von Ferdinand Hauck. I-3 Lieferung. (Leipzig : Eduard Kummer, I883.)

SINCE the appearance of the original work (1845-53) the systematic study of living algæ has, through a more accurate knowledge of the structure and fructification of these plants, led to great changes in their diagnosis and classification. Hence the necessity of a new edition of Rabenhorst's work.

In order to render it more valuable, the preparation of the parts of which it is composed have been intrusted to authors specially conversant with the subjects of which they treat. The first volume, five numbers of which have already appeared, contains the Fungi, and is edited by Dr. G. Winter of Zurich; the second comprises the Marine Algæ (exclusive of the Diatomaceæ); then will follow the Fresh-water Algæ, edited by Herr Paul Richter of Leipzig; the Diatomaceæ, by Dr. A. Grunow of Vienna; and the Frondose Mosses and Hepaticæ, by Herr G. Limpricht of Breslau. To these will succeed works on the Lichens, Chariceæ, and Vascular Cryptogams.

The second volume, which forms the immediate subject of this notice, has been intrusted to M. F. Hauck, who, from his residence on the coast at Triest, has, during many years, had opportunities of studying marine algæ in a living state; and by his connection with German and other algologists, has been able to obtain authentic examples of most of the species. It may also be mentionec that M. Hauck has published "A List of the Algæ of the Adriatic" (Beitr. z. Kenntn. d. adriat. Algen, Wien, I878).

The present work, of which three numbers have appeared, includes not only the algæ inhabiting the Austrian coast and islands of the Adriatic, but also those of the Baltic and North Seas, and the coasts of Heligoland with the adjacent islands : the latter have been found especially rich in species.

In the Introduction to his work, M. Hauck gives instructions for the collection and preparation of the various. 